\title{
Tsensuur kommunistlikus Poola Rahvavabariigis
}

Gaweł Strządała

Teesid: Artikkel võtab vaatluse alla tsensuuri kommunistlikus Poolas. Kirjeldatakse tsensuuri keskameti (Ajakirjanduse, Publitseerimise ja Avalike Esinemiste Peavalitsus; Gtówny Urząd Kontroli Prasy, Publikacji i Widowisk) funktsiooni ja tegevust, aga ka mitteametlikke kontrollimeetmeid, mis rakendusid näiteks riiklikele kirjastustele ja trükikodadele. Uurimuses analüüsitakse näiteid Stalini-aegsete põrandaaluste trükiste nimistust ja mõtestatakse probleeme, mida on pidanud lahendama poola ajaloolased, kes on uurinud nõukogude tsensuuri pärast 1956. aastat. Antakse ülevaade ka põrandaaluste trükikodade rollist 1970. aastatel ja hiljem: nende abil ilmunu täiendas riiklike kirjastajate pakutavat lugemismaterjali ja nende olemasolul on tähtis roll Poola Rahvavabariigi poliitilise opositsiooni sünni juures.

Märksõnad: kommunism, NSVL, opositsioon, põrandaalune ajakirjandus, repressiivne ja preventiivne tsensuur

Totalitaarsetes riikides, kus riik üritas elimineerida inforinglusest kogu informatsiooni, mis oli vastuolus ametliku poliitikaga või polnud lihtsalt soovitatav, valitses poliitiline tsensuur. Täielik kontroll ajakirjanduse, raadio ja televisiooni üle võimaldas totalitaarsel valitsusel kujundada ühiskonda vastavalt eelistatud ideoloogiale. Tsensuuri leidus ka autoritaarsetes maades, ja Teise maailmasõja eelne Poola on hea näide autoritaarsest riigist, kus võimu oli haaranud 1926. aastal Józef Piłsudski nö saneeriv valitsus (Sanacja). Sellegipoolest oli sõnavabaduse piiramine teise Poola Vabariigi ajal üsna leebe. Peamine tsensuuriviis oli olemuselt repressiivne, mis tähendab, et tekste tsenseeriti ja kontrolliti alles pärast avaldamist. Trükikojad olid kohustatud esitama iga trükikoopia siseministeeriumi alluvusse kuuluva sotsiaalse ja poliitilise osakonna esindajatele. Kui trükis ei vastanud valitsuse nõuetele, võeti levist tagasi terve trükipartii. Sellegipoolest oli võimalik otsuse vastu (vähemalt teoorias) protesteerida: kirjastaja võis kaevata tsensuuri otsuse kohtuinstantsile, mis selle teemaga tegeles, so tsensuuriüksuste järelevalvekohtule. Autoritaarne süsteem üritas hoida 
head mainet ja jätta mulje, et riigis valitseb demokraatia. Seetõttu avaldati mõned tsenseeritud tekstid ikkagi avalikus pressis, kuid lõikudel, mida peeti ebasobivaks, olid valged laigud. Lugejad mõistsid suurepäraselt, et artikkel oli tsenseeritud ja sellest puudusid teatud osad (Witek \& Żmigrodzki 2003: 41). Autorite ja kirjastajate seisukohalt oli repressiivsel tsensuuril eeliseid preventiivse tsensuuri ees, mis valitses kommunistlikus Poolas, sest esimene lubas teatud vabadusi ja võimaldas nõuetest kõrvale hiilida. Näiteks võis esitada esimese proovitrükise tsensoritele alles siis, kui raamat oli juba trükitud ja müügis. Kahe maailmasõja vaheline opositsiooniline press kasutas "valgete laikude strateegiat" eesmärgipäraselt. Sealt on tulnud ka väljend "valged laigud ajaloos", mis tänapäevalgi tähistab nõukogude-aegse tsensuuri mõju ajalookäsitlusele. Vahetult enne Teist maailmasõda muutus tsensuur väga rangeks, eriti Saksamaaga piirnevatel Poola aladel. Hea näite selle kohta pakub Władysław Studnicki (Poola germanofiil, kes avaldas 1939. aastal raamatu Algava Teise maailmasõja eel (Wobec nadchodzacej wojny niemecko-sowieckiej), mis konfiskeeriti kohe pärast avaldamist. Kõik kätte saadud eksemplarid hävitati. "Mul on üks neist raamatutest alles," kirjutas autor. "Ma esitasin kohtule kaebuse tsensuuri otsuse vastu. Juulis 1939 kuulati mind üle. Ma kaitsesin tuliselt iga peatükki, aga kui ma jõudsin Nõukogude vägede toetuse mõju käsitleva kohani, kaotasin ma kontrolli ja puhkesin nutma" (Studnicki 1995: 38). Selle raamatu puhul konfiskeeriti terve tiraaž ja keelati ka juurdetrükkimine. Paljudel varasematel juhtudel, mujal kui Saksa piiri lähedal, lubas kohus pärast kaebuse esitamist ja kaasusega tutvumist siiski avaldada ka tsenseeritud tekste - kui mitte tervikuna, siis vähemalt osaliselt.

Teise maailmasõja algus ja Poola Vabariigi okupeerimine tõi kaasa hävitavaid tagajärgi poola rahvuspärandile. Ühelt poolt sakslased ja teisalt venelased sulgesid kõik akadeemilised ja linnaraamatukogud ning konfiskeerisid tohutul hulgal raamatuid. 35000 raamatukogu suleti, 14 miljonit raamatut likvideeriti, sh raamatupoodidest (Witek \& Żmigrodzki 2003: 42). Kahe suurvõimu omavaheline kokkulepe, Molotovi-Ribbentropi pakt kinnitas mõlema osapoole soovi suruda alla kõik Poola iseseisvuspüüded. Natsivastane propaganda keelati Nõukogude vägede poolt okupeeritud piirkondades ja nõukogudevastane propaganda oli lubamatu Saksamaa poolt hõivatud territooriumil. Vene ja Saksa vägede kokkupõrge 1941. aastal põhjustas mõlema tülitseva poole kuritegude vastastikuse tunnistamise. Debatil Katõni massimõrva üle olid rahvusvahelisel areenil iseäranis suured järelmõjud. Stalin lõpetas diplomaatilised suhted Poola valitsusega ja algatas nõukogude-meelse Poola Patriootide Liidu (Zwiqzek Patriotów Polskich; Pobóg-Malinowski 1990: 399). Tuleb rõhutada, et liitlaste tsensuuriüksused ei lubanud avaldada midagi, mis võiks puudutada Katõni temaatikat, sest nad ei tahtnud ärritada oma Nõukogude partnerit. Külma 
sõja ajal kaevati teema uuesti üles Ameerika Ühendriikides, kuid sellegipoolest ei avalikustatud siis veel kõiki juhtumiga seotud dokumente (Zychowicz 2012: 69).

Mis puutub poola hariduselusse NatsiSaksamaa okupatsiooni ajal, siis sel ajal suleti kõik kõrgemad õppeasutused ja enamik keskkoolidest. Olukord oli mõnevõrra parem aladel, mille olid okupeerinud Nõukogude väed, sest seal säilitati mõned õppeasutused, nt Lvivi ülikool. Sellegipoolest pidid ka need alluma venestamisprotseduuridele ja tugevale ideoloogilisele survele. Kõik loengud toimusid ukraina keeles ja akadeemilisele töötajaskonnale rakendus marksismi-leninismi tundmise nõue. Mõnda aega lubati poola uurijatel ja teadlastel küll töötada Lvivi ülikoolis, kuid nad pidid õpetama ukraina keeles. Nagu kirjutas oma memuaarides

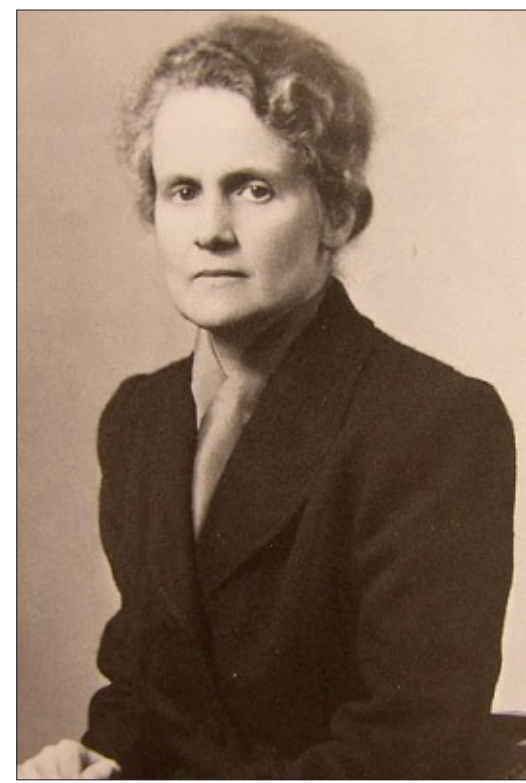

Foto 1. Karolina Lanckorońska. goodreads.com. üks tolleaegne lektor, krahvinna Karolina

Lanckorońska, "raamatuid, mis käsitlesid mitte-materialistlikku filosoofiat või mõnda teist sobimatut valdkonda, või sellised, mis näitasid meie idanaabrit halvas valguses (ja neid oli palju), hoiti luku taga, samas kui pornograafilise kirjanduse alla kuuluv lubati avalikkuse ette" (Lanckorońska 2001: 26-27).

Kui punaväed vallutasid 1944. aastal taas kord Poola alad, rajasid vallutajad Poola Rahvusliku Vabastamise Komitee (Polski Komitet Wyzwolenia Narodowego) peakorteriga Lublinis. Seda juhatasid Kremlile truud marionetid. Organisatsioonis loodi ka propagandaosakond ning selle alluvuses pressi ja informatsiooni jaoskond eesotsas Jerzy Borejszaga. Viimane vastutas trükikodade toodangu kontrollimise eest, võttis vastu otsuseid paberivarude jaotamise ja poliitilise sisukontrolli kohta. Selline korraldus oli Nõukogude propaganda ja tsensuuri süsteemi täpne vaste. Novembris 1955 külastasid Lublinit kaks nõukogude-meelset tsensorit, kes töötasid Vene Nõukogude Föderatiivse Sotsialistliku Vabariigi (Vene NFSV) Haridusasutuste Rahvakomissariaadi alla kuuluvas kirjanduse ja publitseerimise keskvalitsuses - Piotr Gładzin ja Kazimierz Jamróz. Kommunismipooldajatest "nõunikud” olid Poola tsensuurimehhanismide kohta ettekirjutusi tegevate ametlike regulatsioonide autorid. Enne Teise maailmasõja lõppu, 19. jaanuaril 1945. aastal, loodi vastavalt avaliku julgeoleku ministri Stanisław Radkiewiczi dekreedile Ajakirjanduse Kontrolli Keskvalitsus (Centralne Biuro Kontroli Prasy). Ministri pädevusse jäi peamiselt 
opositsiooni kontrollimine, Poola eksiilvalitsuse juhitud vägede (Armia Krajowa) liikmete jälitamine ja tagakiusamine ning avaliku ajakirjanduse kontrollimise protseduurid (Witek \& Żmigrodzki 2003: 42).

15. novembril 1945 nimetati Ajakirjanduse Kontrolli Keskvalitsus ümber Ajakirjanduse, Publitseerimise ja Avalike Esinemiste Peavalitsuseks (Gtówny Urzad Kontroli Prasy $i$ Widowisk). See hakkas kuuluma ministrite nõukogu presiidiumi alluvusse ja pidi kontrollima tekstide vastavust Poola Ühinenud Töölispartei seadustele. Samas varjas 14. juulil 1946 allkirjastatud ameti legaliseerimisdekreedi sõnastus hoolikalt igasugused seoseid selle institutsiooni ja totalitaarse riigi julgeolekuorganite vahel. Uurija Andrzej Krajewski usub, et tsensuuri reguleerivad seadused rikkusid tegelikult nii Poola Rahvavabariigi konstitutsiooni aastast 1952 kui ka administratiivsete protseduuride koodeksit aastast 1960 (Krajewski 2002: 22). Koodeks sedastas, et võimuorganid peavad osutama iga kodanikku puudutava otsuse legaalsele alusele. See oleks pidanud tähendama, et otsustusprotsess on avalik, kättesaadav kirjalikul kujul, ja äramärkimist pidi leidma ka otsusega seotud institutsioon (Krajewski 2002). Poola Rahvavabariik soovis jätta endast mulje kui demokraatlikust riigist, tegelikult aga rikkus valitsus seadusi iga kord, kui võttis vastu otseselt Nõukogude Liiduga seotud strateegilisi otsuseid. See puudutas ka tsensuuri. Järelevalvesüsteemi Nõukogu (Najwyzsza Izba Kontroli) ülevaatus aastal 1966 leidis, et seadusi järgiti hooletult ja ebatäpselt. Sellegipoolest ei meenutanud kaos seda, mis toimus nõukogudeliku võimustruktuuri teistes osades; pigem oli tegu organiseeritud/kalkuleeritud kaosega, mille eesmärgiks oli kommunistliku partei agenda täitmine, isegi kui see tähendas protseduurireeglite ebatäpset järgimist. Poola Rahvavabariigis tulenesid otsused otseselt Poola Ühinenud Töölispartei tollasest tegevuskavast. Täpselt nagu George Orwelli romaanis 1984, sooviti kommunistlikus Poolaski muuta minevikku, et kontrollida olevikku ja mõjutada tulevikku. See põhjustas olukorra, kus isegi kommunistlike vaadetega inimene võis sattuda tsensuuriga vastuollu, sest tema tõekspidamised võisid partei hetkeseisukohtadega ei pruukinud kattuda. Detailsed juhised, mida jagasid laiali Poola Ühinenud Töölispartei Keskkomitee ja valitsuse ministrid, täpsustasid ka seda, mis puudutas sekkumismeetodeid potentsiaalse dissidentluse suhtes. 1946. aasta dekreet nimetas viit tsensuuri põhiobjekti. Nendeks on tegevused, mis:

- ohustavad Poola riigikorda,

- paljastavad riigisaladusi,

- kahjustavad oma tegevusega Poola riigi rahvusvahelisi suhteid,

- rikuvad seadusi või moraalinorme,

- eksitavad avalikkust, jagades tegelikkusega vastuollu sattuvat informatsiooni (Witek \& Żmigrodzki 2003: 44). 
Eriti Nõukogude aja alguses pidasid Poola kommunistid tsenseerimist oma missiooniks ja nõudsid riigikodanikelt ideoloogilist truudust. Ka pärast 1956. aastat, mil isikuvabadused suurenesid ja tagakiusamine vähenes, oodati tsensoritelt ikka kuulekust ja käsutäitmist. Kommunistist ajaloolase ja Poola Rahvavabariigi kunagise välisministri Marian Orzechowski sõnul kontrolliti kõige rohkem neid ajaloolasi, kes kuulusid Poola Ühinenud Töölispartei ridadesse, sest nemad esindasid kogu partei arvamust. "Tsensorid olid veendunud, et parteisse kuuluvad ajaloolased, eriti need, kes olid poliitikas tegevad, on kõige rohkem kohustatud lähtuma oma kõnede ja kirjutiste sõnastamisel partei strateegiast" (Romek 2001: 151). See töötas kahtepidi: kui tsensor avastas parteiliikmest ajaloolase tekstist "ketserlikke" mõtteid, siis ei võinud ta kunagi kindel olla, kas see mõte esindab partei uut strateegiat, mille kohta teksti autor polnud veel juhtnööre saanud, ja mis võib tulevikus tegelikult ka teostuda, või on tegu päris dissidentlusega. Tsensorid kartsid, et neid võidakse süüdistada liigses innukuses, sest prioriteet oli tsenseerimise kvaliteet, mitte kvantiteet. Kommunistid pooldasid preventiivset tsensuuri ja seetõttu ei muudetud korrektsioone tekstis nähtavaks. Eesmärk oli panna lugeja uskuma, et konkreetse kirjatüki sõnad ja mõtted on autori omad, isegi kui nendes oli tehtud tähelepanuväärseid muudatusi. Ajakirjanikud, kirjanikud ja uurijad, kes tegelesid vastoluliste teemadega, proovisid tsensoreid petta, väljendades oma vaateid vihjamisi ja kasutades teisi trikke. Mõnikord õnnestus neil tsensoritest mööda hiilida, kuid teinekord pidid nad siiski oma tekstid ametliku poliitikaga kooskõlla viima. Ka akadeemilised väljaanded allusid kontrollile. See kuulus teadustöö juhendajate ülesannete hulka, kes (nagu tänapäevalgi) mõjutasid uurimuse sisu, ainult et siis oli nende mõju nii sisuline kui ka poliitiline. Juhendajapoolne tsensuur puudutas eelkõige doktori-ja habilitatsioonidissertatsioone, mida avaldati trükituna. Magistritöid tsenseeriti vähem tõenäoliselt, sest neid ka avaldati harva (Romek 2001: 159). Mõnikord võltsisid kommunistlikult meelestatud tsensorid uurimuse algtekste ja dokumente, eriti neid, mis puudutasid Poola Kommunistliku Partei ajalugu, sest see oli Poola Ühinenud Töölispartei eellane (Romek 2001: 167).

Kontrolliprotseduurid olid mitmemõõtmelised ja komplekssed, ja koosnesid mitmetest etappidest: raamatute ja muude mitteperioodiliste publikatsioonide puhul oli see kolmeastmeline ja perioodika puhul neljaastmeline. Regulaarne kontroll algas ülevaatliku inspektsiooniga, mille käigus luges tsensor läbi käsikirja, viis sisse soovitavad muudatused ja andis nõusoleku trükkimiseks; see etapp perioodikat ei puudutanud. Järgmises faasis hinnati proovitrükieksemplare. Siis lugesid tsensorid läbi versiooni, mis oli mõeldud müügiks, ja kui see sobis, alustati levitamist. Viimases etapis korrati protseduuri veel korra, et kontrollida tsensorite tööd - juba müügil olevaid raamatuid loeti, ja kui avastati kahtlustäratavaid lõike, võeti terve tiraaž müügilt ära ning tsensoreid 
karistati. Karistused ei olnud kuigi rängad, eksimuse teinud ametnikke koheldi pigem kui ebakompetentseid töötajaid, mitte kui riigi vaenlasi. Oskamatut tsensorit ootasid edaspidi lihtsamad tekstid (Witek \& Żmigrodzki 2003: 45-46). Et parandada tsensuuri kvaliteeti, korraldati koolitusi ja koosolekuid, mille käigus tutvustati partei hetkesuundi ja -strateegiaid. Tsensoritele, kes selles ametis töötasid, ei tehtud ajupesu; neile ei esitatud moonutatud informatsiooni ega propagandat. Selle asemel arutati üheskoos propagandakampaania sõnumi tähendust ja eesmärke. Trendid tsenseerimises - ideede, mõtteavalduste kontrollimises ja lubatud teemade nimekirjas - muutusid regulaarselt. Stefan Kisielewski on kirjeldanud kommunistliku tsensuuri põhijooni järgnevalt:

a) tuleb panna lugejad uskuma, et tekstid esindavad autori seisukohti,

b) tuleb panna kirjutajad kasutama teatud arutluskäike ja mõtteavaldusviise, mis vähendaksid ohtu tsenseerimisele (tsiteerinud Krajewski 2002: 24).

Kommunismiajal polnud tsensuur osa ametlikust poliitikast, nagu seda polnud ka eriteenistused ega politsei (Poola versiooni, 'Kodanike Politsei', Milicja Obywatelska nimi viitas sellele, nagu oleks tegemist kodanike poolt rajatud institutsiooniga korra tagamiseks, mitte tavalise riikliku korrakaitseasutusega). 20. sajandi poola kirjanik, helilooja ja poliitik Stefan Kisielewski on öelnud, et tsensuurirakukestel oli tema hinnangul kaks funktsiooni: hävitada teatud soovimatuid aspekte igapäevases reaalsuses, ja teiseks luua uus irreaalsus; st logokraatia. Mõlemad mainitud funktsioonid realiseerusid samaaegselt ja salastatult, ning see kahjustas mõõtmatult autoreid, kirjandust ja kogu kultuuri tervikuna. Autorid olid sunnitud ideoloogiaga kohanduma ja alla kirjutama omaenda mõtete moonutatud versioonile. Hruštšovi sula alguses sai Stefan Kisielewski alustada debatti Mieczysław F. Rakowski, poola kommunisti, ajaloolase ja ajakirjanikuga, kes oli varem kritiseerinud üht Kisielewski artiklit. Nüüd sai "autor" lisada argumendi, mida enne poleks olnud võimalik vaidlusse tuua: "Ta [Rakowski] arvas, et ta seadis kahtluse alla minu ideed, kuigi ma ei kirjutanudki seda artiklit. See oli tsensor, kes selle artikli kirjutas," ütles Kisielewski (vt Bartyzel 2012).

Ajakirjanduse, Publitseerimise ja Avalike Esinemiste Peavalitsus kontrollis peagi kogu meediat. See kontrollis ka kõiki teisi institutsioone, mille puhul oli oht, et nad väljendavad valitsusega mitte kooskõlas olevaid mõtteid. Tegelikkuses ei saanud seda juhtuda, sest avalik meedia oli Nõukogude-meelsete tsensorite valve all, kuid nagu juba mainitud, arenes partei poliitika pidevalt, ning vahel võis juba süsteemivastaliseks nimetatud sisu aja jooksul saada vastuvõetavaks ja vastupidi. Loomulikult töötas tsensuur ka eeletappides, mil kirjastajad valisid välja vaid teatud kirjutisi, et vähendada võimalikku sanktsiooniohtu. Tuleb meeles pidada, et kommunistlik riik oli ainukene tööandja 
ja tootmisvahendite jagaja, mistõttu sai riik manipuleerida väljaandjatega - ja seeläbi karistada allumatuid autoreid - ka näiteks paberiressurside jaotamise kaudu. Katoliikliku alatooniga ainuke suhteliselt autonoomne sotsiaalse sisuga ajakiri Tygodnik Powszechny (Üldine Nädalaleht) pidi tihti selliseid sanktsioone taluma.

Kõige suuremat kahju kultuurile tegi Poola Rahvavabariigis 1940. ja 1950. aastatel täide viidud otsus hävitada paljud maailmasõdade-eelsed raamatud. 2. veebruaril 1949 keelati Poola Ühinenud Töölispartei poliitbüroo ja Keskkomitee pleenumil ära kõik "vaimulik" ja "reaktsiooniline" kirjandus. Selle hävitamine pidi täide viidama suvevaheajal, et mitte ärritada õpetajaid ja õpilasi (Żmigrodzki 2002). Raamatute nimekirjad olid ülisalajased; teosed ise saadeti haridusnõukogudesse ja sealt edasi vanapaberi kogumiskohtadesse, kus need hävitati. Selle tegevuse põhieesmärk oli kustutada kultuurimälu. See polnud kindlasti ainuke selletaoline juhtum, sest sama juhtus ka näiteks Natsi-Saksamaal, kus raamatuid põletati avalikult, kuid Poola puhul oli tegu mitte väljaspoole suunatud ettevõtmisega, vaid mahavaikitud massihävitusega. Raamatupoodide ja linnaraamatukogude jaoks tehti registrid. Mõned raamatukogutöötajad ei tahtnud parteiga koostööd teha, kuid neid sunniti siiski korraldusi täitma. Nii mitmelgi puhul keelati mõne autori kogu looming, näiteks Zofia Kossak-Szczucka ja Ferdynand Goetel olid keelatud autorite nimekirjas. Kõige pikem keelatud kirjanduse nimekiri on säilinud aastast 1951. Selle sisuks on kolm eraldi nimekirja: esimene katab täiskasvanute- ja noortekirjanduse (kokku 1682 kirjet), teine "vananenud" sotsiaal-poliitilised teosed (238 kirjet), ja kolmas lastekirjanduse (562 kirjet). Hirmul olid suured silmad, kõik need raamatud hävitati eelkõige ideoloogilistel põhjustel. Nii mõnegi raamatu puhul, mis nimekirja sattus, tundub põhjendus olevat arusaamatu või isegi absurdne. Võis juhtuda, et raamat keelati ära ainult seetõttu, et see avaldati soovimatus kirjastuses, ning sama raamatu (nt Grimmide muinasjuttude) teine trükk jäeti alles, sest selle avaldas teine kirjastaja. Esikohale seati nõukogude-vastase kirjanduse ärakaotamine, nt Jan Kucharzewski (ajaloolane, poliitik, Poola peaminister aastatel 1917-1918) teos Od biatego caratu do czerwonego (Valgest tsaarist punaseni). Józef Piłsudski, kes oli teine tuntud Poola iseseisvusaegne autor, oli keelatud, ja samuti temast rääkivad raamatud. Kogu kirjandus, mis puudutas natsionaaldemokraatiat või mis oli seotud Roman Dmowski (poliitik, natsionaaldemokraatliku partei üks rajajatest) isikuga, ei olnud lubatud. Raamatud, mis käsitlesid idapoolseid piirialasid (J. Bartoszewiczi, kes oli natsionaaldemokraatlik poliitik, ametilt arst, raamat Znaczenie polityczne Kresów Wschodnich dla Polski (Poola idapoolsete piirialade poliitiline tähendus), ja isegi Kornel Makuszyński - poola laste- ja noortekirjaniku - Uśmiech Lwowa (Lvivi naeratus)) olid keelatud kirjanduse nimekirjas. Ka juuditeemad polnud 


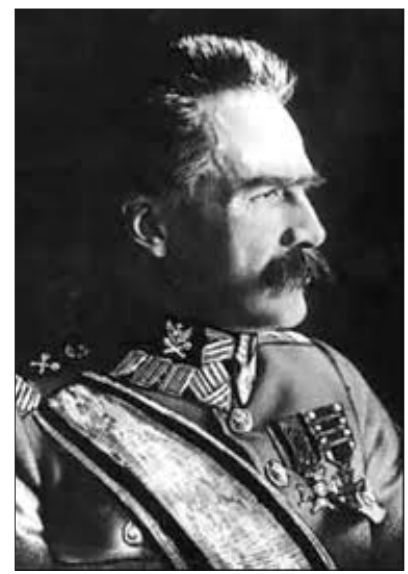

Foto 2. Józef Pitsudski. en.wikipedia.org.

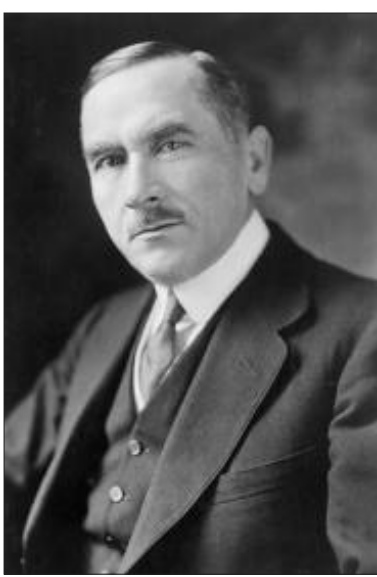

Foto 3. Roman Dmowski. en.wikipedia.org.

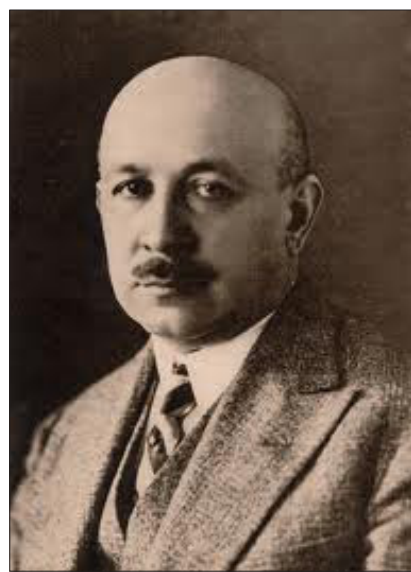

Foto 4. Kornel Makuszyński. pl.wikipedia.org.

aktsepteeritavad, eriti sellised, mis sisaldasid antisemiitlikku sisu. Välja arvatud tõlked Lääne-Euroopa ja Ameerika autorite teostest, mis rääkisid Poolat puudutavatel teemadel, oli väliskirjandus keelatud, näiteks Margaret Mitchelli Tuulest viidud, aga ka Agatha Christie teosed. Kodumaisest ilukirjandusest konfiskeeriti Helena Mniszkówna teosed. Nimekirja kuulus ka raamat, mis õpetas noortele tütarlastele kombekat käitumist. Kummalised otsused hõlmasid raamatut porganditest ( $O$ uprawie marchwi pastewnej (Porgandikasvatusest)). Selle keelu põhjuseks toodi asjaolu, et see raamat propageeris kolhooside asemel individuaalpõllumajandust (Witek \& Żmigrodzki 2003: 50).

Pärast 1956. aastat muutus tsensuur nõrgemaks, kuid see ei saanud olematuks teha fakti, et väärtuslikem osa kultuuripärandist oli Stalini ajal juba hävitatud. Keelustati kõik kodanikualgatused ja demokraatlikud trendid, sest ideaalne totalitaarne riik tuli ehitada teistsugusele vundamendile. Kogu "ebamugav" kultuuripärand, mis oli pärit Teise maailmasõja eelsest Poola Vabariigist, pidi kustutatama. Kirjanikud, ajaloolased, majandusteadlased pidid unustama sõnavabaduse mõiste koos kõikide seisukohtadega, mis võisid tuua kahju kommunistlikule riigikorraldusele.

Tuleb taas korrata, et kommunistlik riik oli ainus tööandja ja monopolist, mis andis võimaluse sanktsioneerida sõnakuulmatuid kodanikke, võttes neilt ära kõik majanduslikud hüved ja jättes nad nälga. Sellele lisaks oli totalitaarne riik elanikele vanglaks, sest sealt ei saanud keegi lahkuda ilma vastava loata. Tomasz Strzyżewski, endine kommunist ja tsensor, kes põgenes Poola Rahvavabariigist ja paljastas välisriikidele tõe seal valitseva tsenseerimise 


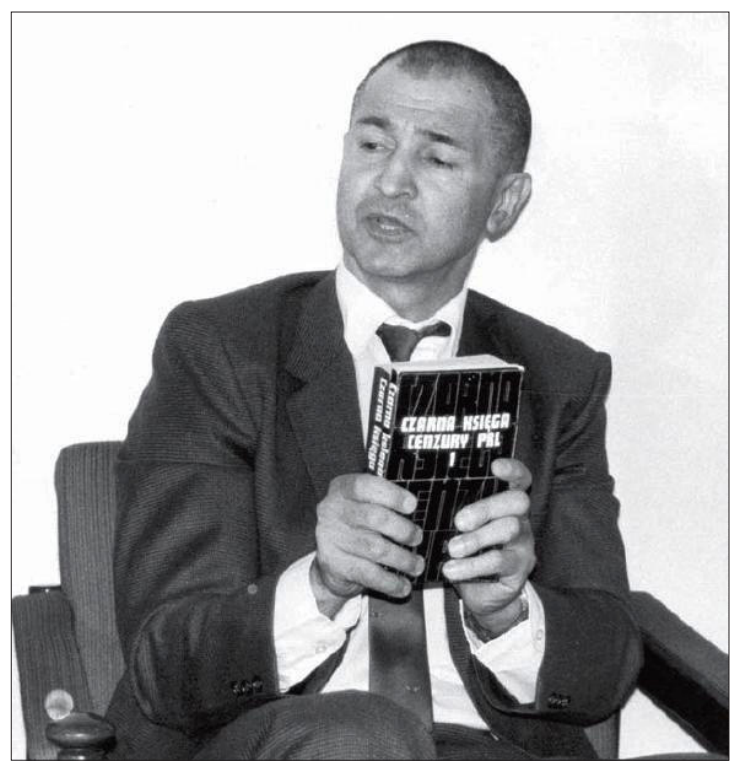

Foto 5. Tomasz Strzyżewski oma teosega Czarna Księga Cenzury PRL. pobierz.dlapolski.pl/2011/01/matrix-czyprawda-selektywna.html.

kohta, võttis kogetu kokku, öeldes: "Tsensuur oleks toiminud ka ilma vastava institutsioonita. Valitsus vajas institutsiooni vaid selleks, et see defineeriks ühtsed käitumispõhimõtted problemaatilistes situatsioonides. Tsensuur sündis spontaanselt, ning see oli tööandja ja töötaja vaheliste suhete otsene tulem" (Strzyżewski 2006: 10-11).

Ajakirjanikud ja kultuuritegelased suutsid jätkata oma tööd. Mõned tundsid end etteantud juhiseid järgides mugavalt, teised nõustusid tsensuuri parandustega hirmu või konformismi tõttu. Kommunistlik Poola ei olnud iseseisev riik; see rakendas Brežnevi ettekujutust “piiratud suveräänsusest”. Kuid tegelikkuses oli Poola sõltuvus NSVList veelgi tugevam ja sellel oli mitmeid tahke. Poola ajaloolane Czesław Madajczyk on väitnud: “Aastal 1968 pärinesid tsensorite kommentaarid nõukogude ajaloolaste sulest, parandades fakte, mis puudutasid Saksamaa ja Venemaa vahelist pakti" (Romek 2001: 136-137). Sellele paktile osutamata oli võimatu Teisest maailmasõjast kirjutada, kuid sellegipoolest oli rangelt keelatud mainida Molotovi-Ribbentropi pakti salaprotokolli, mis kirjeldas mõjusfääride jagamist. Katõni massimõrv jäi tabuteemaks kommunismiaja lõpuni. Poola ja Venemaa suhted ning 1920. aastal toimunud sõda nende kahe riigi vahel kuulusid samasse kategooriasse, ning kui neid mainiti, siis fakte moonutades. Poola ajaloolased pidid paljudes küsimustes nõukogude uurijatelt nõu küsima. Tänapäevani tuleb ette debatte poola ja saksa, poola ja 
ukraina, või poola ja vene uurijate vahel, kuid nüüd on need võrdsete partnerite arutelud, mille eesmärgiks on siluda eriarvamusi ja leida ühine ajalookäsitlus. Varem surusid vene teadlased peale üheainsa tõlgenduse, mis esitas Poola ja Vene suhetest väga kallutatud pildi. Jerzy Tomaszewski, vanema ajaloo ekspert, mainib, et pärast 1968. aastat, mil juudid Poolast välja aeti, ei olnud lubatud kirjutada juudi kogukonnast. Peeti paremaks seda teemat vältida, et mitte anda positiivseid ega negatiivseid hinnanguid (tsiteerinud Romek 2001: 244-245). Väga iseloomulik kommunistlikule Poolale oli see, et tsensuurist ei tohtinud kirjutada. See kitsendus kehtis kuni aastani 1990, mil tsensuur tühistati (Romek 2001: 68).

Ajaloolane Tomasz Strzembosz kirjutas uurimuse Poola põrandaalusest valitsusest ja Nõukogude okupatsioonist ida-aladel Poola Rahvavabariigi aastatel, oma töö sai ta avaldada alles pärast 1989. aastat, sest varem oleks avaldamine olnud ohtlik. Ta on öelnud: "See on alandav, et minu uurimusi pidi hoidma salajas hirmust julgeolekukomitee ees, aga samamoodi ka hirmust minu kolleegide ees: hirmust, et keegi võiks minu peale kaevata, alustada juurdlust või sundida mind teemat kõrvale panema" (Romek 2001: 202).

Mõned juhtumid võib liigitada ka naljakate kilda. Ajaloolane Tomasz Szarota meenutab episoodi, mis juhtus enne tema doktoriväitekirja avaldamist. Viimaseid korrektuure tehes leidis ta kirjavea, mida ta varem polnud märganud. Ta oli jätnud kogemata välja ühe tähe sõnas rustyfikacja (ruraliseerumine), mistõttu oli kirjas hoopis rusyfikacja - venestamine. Kui ta oleks selle avastamata jätnud, oleks ta tõenäoliselt sattunud hiljem probleemidesse (Romek 2001: 208).

Tsensuuri olemasolu sundis inimesi aeg-ajalt midagi ette võtma, näiteks koostati kuulus 34 kiri, millele kirjutasid alla 34 poola kultuuritegelast eesotsas Antoni Słonimskiga (poola poeet ja näitekirjanik). Selles võis lugeda: "Paberi jaotamise piiramine kirjastustele ja tsensuuri rakendamine ajakirjanduses ähvardab pidurdada meie rahvusliku kultuuri arengut. Meie, allakirjutanud, peame avaliku arvamuse olemasolu, õigust kriitikale, sõnavabadust ja juurdepääsu usaldusväärsele informatsioonile arengu vääramatuks osaks ning kodanike ja riigi heaolu aluseks. Me nõuame muutust kultuuripoliitikas, mis peab olema kooskõlas Poola konstitutsiooniga" (Albert 1989: 825). Võimud ignoreerisid kirja ja kommunistliku võimuladviku reaktsioon tuli ilmsiks alles siis, kui Raadio Vaba Euroopa ja välispress 34 kirja avaldasid. Vastulauseks avaldas Poola Ühinenud Töölispartei Keskkomitee kirja, millele oli alla kirjutanud 600 võimukuulekat autorit ja need, kes kuulusid kommunistide mõjuvõimu all olevasse Kirjanike Liitu, mille liikmeskonnast 26\% kuulus parteisse. Paljud välisautorid ja kultuuritegelased Lääne-Euroopast elasid kaasa 34 kirja algatajatele, kes pidid hiljem kannatama mitmeid sanktsioone (nt avaldamiskeelud ja piiratud 
paberiratsioonid väljaande Tygodnik Powszechny jaoks, sest Jerzy Turowicz, selle peatoimetaja, oli üks allakirjutanutest (Albert 1989)).

1960. aastad olid Poola kultuurile keerulised. Autoreid, keda peeti reaktsioonilisteks, ei tohtinud avaldada; ka noorte autorite teosed ei leidnud teed publikuni. Kõige paradoksaalsem juhtum puudutas Adam Mickiewiczi näidendi "Dziady" ("Kerjused") lavastamisluba aastal 1968 - see keelati väidetavalt Nõukogude-vastase sisu tõttu. Näitemäng oli kirjutatud juba 19. sajandil ja seega ei saanud see kuidagi kommunismile viidata. Publik elas eriti positiivselt kaasa neile näidendi osadele, mida kommunismimeelsed tsensorid olid kritiseerinud, ja selle tulemusel võeti see mängukavast välja. Otsus põhjustas proteste, mida kommunistid vägivaldselt maha surusid (Albert 1989: 879). Poola Kirjanike Liidu erikoosolekul nimetas Stefan Kisielewski süsteemi "ignorantide diktatuuriks" ja seetõttu sattus ta hiljem tundmatute ründajate kallaletungi ohvriks.

1960. aastatel kirjutas satiirik Janusz Szpotański koomilise ooperi "Cisi i gęacze" ("Tasased ja kaagutajad"), mille ta lavastas isiklikest vahenditest. See komöödia esitas teravat satiiri kommunistliku partei aadressil. Szpotański saadeti kolmeks aastaks vanglasse (Albert 1989). Repressioonide ohvriks langesid ka Jacek Kuroń ja Karol Modzelewski kirjutise eest "Avatud kiri parteile" (List otwarty do Partii; Albert 1989: 851-852). Teised, kes pidid sanktsioone taluma, olid nn Mägironijad (Taternicy), kes levitasid keelatud kirjandust, nt Jerzy Giedroyći poolt Pariisis toimetatud ajakirja Kultura.

1970. aastate lõpus elustus põrandaalune kirjanduslevi. Teoste põrandaalune kirjastamine pakkus seadusevastast ligipääsu võimuvastastele ideedele. Selline levikuviis oli elutähtis ka kirjanduse suurteoste seisukohalt, mis oli sageli keelatud kirjanduse nimistus - Poola lugejate kontakti nii poola kui välismaiste suurteostega üritati piirata. Julgeimad avaldasid põrandaalustes kirjastustes ka materjale ajaloo kohta.

Aastal 1980 asutati Lech Walesa juhtimisel Poola kaubandusühistute liit Solidarność (Solidaarsus), ja selle põhikirja kolmas postulaat puudutas tsensuuri. Mõjutatuna Gdanski kokkuleppest andis valitsus välja akti, mis piiras Ajakirjanduse, Publitseerimise ja Avalike Esinemiste Peavalitsuse rolli (Radzikowska 1990: 5). Peamine erinevus uue akti ja 1946. aasta dekreedi vahel oli see, et kõik tehtavad korrektiivid tsenseeritud tekstis pidid nähtavad olema. Veelgi enam: autor võis tsensuuri otsuse edasi kaevata halduskohtusse. Selle akti kehtivus kaotati taas eriolukorra tingimustes (Stan Wojenny; 1981-1983) aastal 1981, mil ennistati 1946. aasta dekreet. See otsus mõjus eriti halvavalt akadeemilistele publikatsioonidele, mis pidid jällegi läbima kõik tsensuurietapid. Muudatus, mis puudutas tsensuurikorrektsioonide nähtavaks jätmist, jäi jõusse, kuigi tegelikkuses said ainult katoliiklikud ajakirjad sellest õigusest kasu. 
29. jaanuaril 1990. aastal läks Poola Ühinenud Töölispartei laiali ja peatselt pärast seda kaotati tsensuur. Akt, mis selle teatavaks tegi, jõustus 6. juunil 1990 (Romek 2001: 35-36). Tuleb pöörata tähelepanu faktile, et Tadeusz Mazowiecki valitsusel kulus neli kuud, kaotamaks uues Poolas Vabariigis tsensuuri institutsioon.

Demokraatlikus Poolas tänapäeval tsensuuri ei eksisteeri, kuid toimivad enesetsensuuri erinevad vormid, mis hoiavad endiselt tabuteemasid varjus. See on mõnede ringkondade jaoks kohustuslik; nendes koheldakse teatud rühmi või arvamusi halvakspanu ja seltskonnast väljatõukamisega. Pärast 1989. aastat on kanda kinnitanud termin "poliitiline korrektsus", mis tuli Poolasse läänemaailmast. Poliitiline korrektsus, mida võib tänapäeva Poolas kohata keskklassi tõusikute ja snoobide hulgas, eeldab teatud enesetsensuuri. Seda tüüpi tsensuur keelab rääkimast teatud teemadel või kirjutab ette reegleid, mis moel tundlikke teemasid käsitleda. Need, kes on poliitkorrektsuse suhtes kriitilisel arvamusel, nimetavad olukorda "pehmeks tsensuuriks". Loomulikult on nimetatud uuel trendil, mis sai alguse Ameerika Ühendriikides, palju pooldajaid, sest see on seotud avatuse ja tolerantsiga.

Poola kodanike teadmised nii pagulaskirjandusest (1939-1989) kui ka põrandaalusest kirjandusest (1976-1989) on napid, sest pole tehtud piisavalt jõupingutusi emigreerunud kirjanike teoste kirjastamiseks ja kättesaadavaks tegemiseks tänapäeva Poola auditooriumile. Siin toimib veel üks kaasaegne tsensuuri vorm: autorikaitse. Näiteks emigreerunud kirjaniku Józef Mackiewiczi teoste autoriõigused päris Nina Karsov-Szechter, kes on Londonis asuva kirjastuse Kontra omanik. Hulk poola kirjastusi üritas tulutult Mackiewiczi kirjastusõigusi saada, kuid ei saanud, sest tema teosed heitsid negatiivset valgust nii kommunistlikule olustikule kui ka emigrantidele ja opositsioonile. Kirjastajate ja kirjandusringkondade protest lõppes sellega, et mõned vähem vastuolulised tekstid on nüüdseks Poolas avaldatud, kuid mitte kõik. Nina Karsov-Szechter kommenteeris juhtunut nii: "Ma olen nõus kirjaniku teoste avaldamisega Poolas nimetatud autori tahte ja omaenda veendumuste vastaselt. Józef Mackiewicz oli veendunud, et ma ei teeks midagi, mida tema ei soovi, ja seetõttu ma pärisingi õigused tema teostele" (Witek \& Żmigrodzki 2003: 65). On tõsi, et Mackiewicz ei lubanud Poola Rahvavabariigi institutsioonidel oma töid avaldada (need olid tol ajal niikuinii keelatud). Samal ajal oli ta nõus põrandaaluse levitamisega; sealt sai ta ka idee rajada põrandaalune kirjastus Kontra. Olukorra, kus olulise kirjaniku teosed pole avalikult kättesaadavad ka pärast Poola riigikorra muutumist, säilimine on ilmselt ajendatud soovist takistada Mackiewiczi kirjutiste levikut. Selle näite varal näeme, et ka autoriõigused võivad osutuda tsensuurivormiks ja saada kaikaks rahva vaimse arengu kodarais. 
Kokkuvõtvalt võib öelda, et käesolev artikkel kirjeldas ülevaatlikult tsensuurimehhanisme, mis toimisid Poolas 20. sajandil, iseäranis kommunismi ajastul. Totalitaarse võimuaparaadi poolt peale surutud tsensuur oli nii preventiivne kui ka represseeriv; lisaks sellele toimis ka mitteametlik enesetsensuur. Auditoorium ei teadnud kunagi, kas tsenseerijad olid teksti töödelnud või mitte (st kas tegemist oli autori originaalsõnastustega), sest selle kohta ei jäetud mingit märget. Sellise praktika eesmärgiks oli veenda lugejaid, et autori mõttemallid ühtivad kommunistliku partei omadega. Veidi hiljem, 1980. aastatel viidi tsensuuriseadusse sisse muudatus, mis nägi ette, et tsensuur peab olema tehtud läbipaistvamaks ja auditooriumile nähtavaks. Järgmisel aastal alanud eriolukord aga sundis peale järjekordse tagasisammu: tühistati suurem osa seadusemuudatuse punktidest. Ka tsensuurist või selle ajaloost kirjutamise keeld jäi kehtima kuni taasiseseisvumiseni.

\section{Tõlkinud Liisi Laineste}

\section{Kirjandus}

Albert, Andrzej [pseud; Roszkowski, Wojciech] 1989. Najnowsza historia Polski 19181980 [Poola lähiajalugu 1918-1980] IV. Warsaw: Krag.

Bartyzel, Jacek 2012. Stefan Kisielewski jako publicysta i "zwierze polityczne" [Stefan Kisielewski. Ajakirjanik ja "poliitiline loom"]. Organizacja Monarchistów Polskich. Portal legitymistyczny (http://www.legitymizm.org/stefan-kisielewski - 5. november 2012).

Krajewski, Andrzej 2002. Cenzura i ci kłopotliwi literaci [Tsensuur ja tülikad kirjanikud]. Odra 2, lk 22-29.

Lanckorońska, Karolina 2001. Wspomnienia wojenne [Sõjamemuaarid] 22 IX 1989 - 5 IV 1945. Kraków: Znak.

Pobóg-Malinowski, Władysław 1990. Najnowsza historia polityczna Polski. Okres 19391945 III [Poola lähiajalugu. 1939-1945]. Gdańsk: Graf.

Radzikowska, Zofia 1990. Z historii walki o wolność stowa $w$ Polsce. Cenzura $w$ PRL $w$ latach 1981-1987 [Lõike Poola sõnavabaduse ajaloost. Tsensuur Poola Rahvavabariigis 1981-1987]. Kraków: Towarzystwo Autorów i Wydawców Prac Naukowych Universitas.

Romek, Zbigniew 2001 (toim). Cenzura w PRL. Relacje historyków [Tsensuur Poola Rahvavabariigis. Ajaloolaste ülestunnistus]. Warsaw: Neriton, IH PAN.

Strzyżewski, Tomasz 1977. Z czarnej księgi cenzury w PRL [Poola tsensuuri must raamat]. Warsaw: Aneks.

Strzyżewski, Tomasz 2006. Matrix czy prawda selektywna? Autocenzorskie retrospekcje [Maatriks või osaline tõde? Tagasivaateid enesetsensuuri]. Wrocław: Wektory. 
Studnicki, Władysław 1995. Tragiczne manowce. Próby przeciwdziałania katastrofom narodowym 1939-1945 [Traagiliselt eksiteele viidud. Püüded ära hoida rahvuslikku katastroofi aastatel 1939-1945]. Gdańsk: Mariol.

Szpotański, Janusz 1990. Zebrane utwory poetyckie [Luulekorpus]. London: Puls Publications.

Treść listu 34 [34 kiri] (http://prl.republika.pl/Untitled-19.htm - 5. november 2012).

Zychowicz, Piotr 2012. Zdrada sojuszników [Liitlaste reetmine]. Uważam Rze 17.-23. september, 38/39, lk 68-70.

Żmigrodzki, Zbigniew 2002. Cenzura PRL. Wykaz książek podlegających niezwtocznemu wycofaniu [Tsensuur Poola Rahvavabariigis. Nimekiri koheselt hävitatavatest raamatutest]. Wrocław: Norton.

Witek, Jadwiga \& Żmigrodzki, Zbigniew 2003. "Polityczna poprawność" w III Rzeczypospolitej [Poliitiline korrektsus kolmandas Poola Vabariigis]. Radom: Polskie Wydawn Encyklopedyczne Polwen.

\section{Summary}

\section{Censorship in the People's Republic of Poland}

Gaweł Strządała

Keywords: repressive and preventive censorship, underground press, opposition, USSR, communism

This article discusses the topic of censorship in the communist Poland. It presents a description of the functioning of the office of censorship (Main Office for the Control of Presentations and Public Performances; Główny Urzęd Kontroli Prasy, Publikacji i Widowisk) as well as other forms of informal influence on the authors working for public publishing houses. The underground publications suppressed during the Stalin era as well as difficulties encountered by Polish historians after 1956 will be the subject of the analysis. Furthermore, the article indicates the complementary role of the underground publishers after 1970. These publishing houses had a significant impact on the birth of political opposition in the communist Poland. 